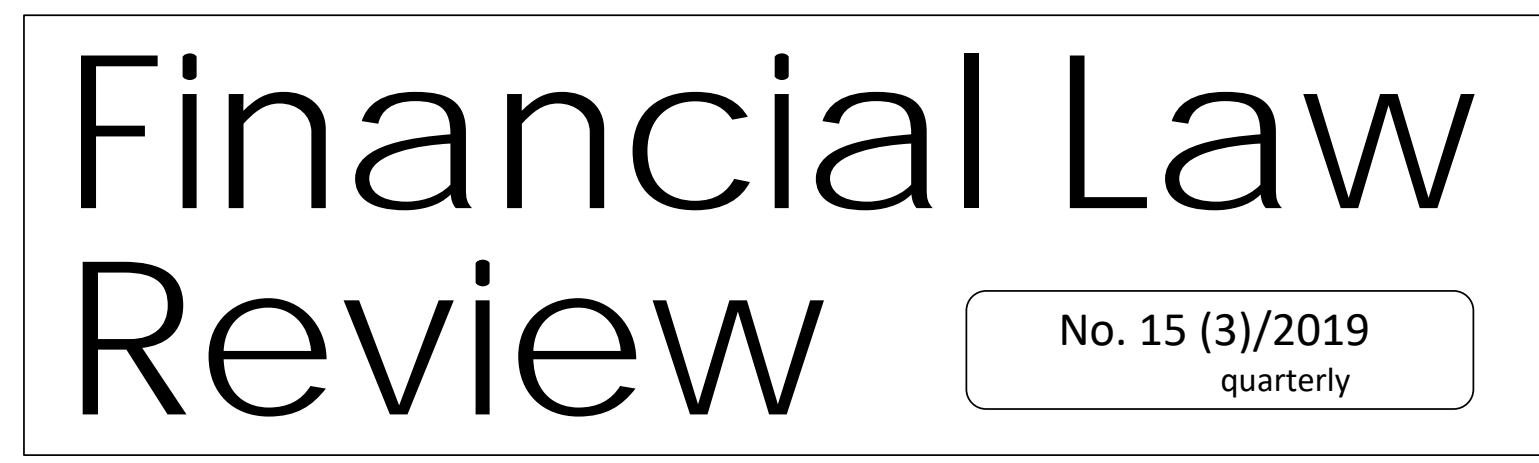

UNIVERSITY OF GDAŃSK • MASARYK UNIVERSITY • PAVEL JOZEF ŠAFÁRIK UNIVERSITY • UNIVERSITY OF VORONEZH http://www.ejoumals.eu/FLR

\title{
REPEALED ACT ON SPECIAL LEVY OF RETAIL CHAINS IN THE SLOVAK REPUBLIC - MEMENTO FOR SLOVAK TAX LEGISLATION $^{1}$ ADRIÁN POPOVIČ *
}

\begin{abstract}
The repealed special levy of retail chains has triggered numerous reactions and discussions in the Slovak Republic during its short existence. The author focuses on a brief factual and time chronology of the existence of this act from its adoption to its abolition. In connection with this, the author analyzes and evaluates selected aspects of the special levy of retail chains, its particulars, deficiencies in its implementation and theoretical-legal bases in the context of knowledge arising from the modern science of tax law. Subsequently, the author assesses the justification for suspending its application by the European Commission and its possible contradictions with European Union law. Taking into account the specific shortcomings of the adoption process, the author also focuses on examining compliance with the governmental rules set out in the RIA 2020 - better regulation strategy. After obtaining the research conclusions from the evaluation of the above mentioned aspects, it
\end{abstract}

\footnotetext{
${ }^{1}$ This paper has been written as part of the APVV-16-0160 grant project entitled: "Tax Evasion and Avoidance (Motivation Factors, Creation, and Elimination)".

* Researcher at the Department of Financial Law, Tax Law and Economy, Faculty of Law, Pavol Jozef Šafárik University in Košice, Slovak Republic. The author specializes mainly in the area of substantive tax law, procedural tax law and the European Union budget. He is co-author of 2 scientific monographs and more than 14 scientific publications. Contact email: adrian.popovic@upjs.sk.
} 
will be possible to confirm or disprove the hypothesis whether the adoption of the Act on Special Levy of Retail Chains was justified, and this can be achieved by considering the quality of its preparation and implementation and the necessity of its abolition, and the adopted conclusion will also be an assessment criterion for assessing the level and quality of the current tax legislation in the Slovak Republic and its implementation in accordance with the requirements set out in the RIA 2020 - better regulation strategy. The author mainly used the scientific method of analysis, synthesis and comparison.

Key words: Tax, levy, retail chain, state aid, legislation, tax law science

\section{JEL Classification: K33, K34}

\section{Introduction}

On $13^{\text {th }}$ December 2018, the Slovak legislature adopted an Act on Special Levy of Retail Chains [Act on Special Levy of Retail Chains; amendment of Act no. 595/2003 Coll. on Income Tax as amended, hereinafter referred to as the "Act on Special Levy of Retail Chains"], which entered into force on 01 January 2019. At that time, despite the detailed and reasoned decision of the President of the Slovak Republic to return the Act [Kiska 2018], the Slovak legislature enact a new special levy (more precisely, a new $\operatorname{tax}^{2}$ ) [Bohác 2013: 221] on the turnover of retailers who sold food to final consumers and which retailers should have paid after meeting the statutory conditions.

The aforementioned in the Slovak Republic has caused a great wave of resentment, in particular by retail chains, the professional public and part of the opposition parliamentary political spectrum. The accompanying phenomenon of the preparation and adoption of this new levy (tax) was an initiative - a complaint of $21^{\text {st }}$ December 2018 initiating an EUlevel procedures relating to the implementation of competition policy [State Aid SA.52194 (2018/FC)], because of the absence of public debate, ambiguity, alleged discriminatory nature and possible conflict with European Union law pursuant to Article 108 of the Treaty on the Functioning of the European Union (hereinafter: TFEU) ${ }^{3}$.

\footnotetext{
${ }^{2}$ Recently, there has been a trend in the Slovak Republic to name taxes by other synonymous names, because of their greater public acceptance, ignoring professional and scientific conclusions, and enforcing political decisions without correcting them sufficiently. This is also the case here, where a special levy on retail chains within the meaning of the act clearly fulfilled all the material features of the tax, and thus was also a tax. However, the issue of taxes and fees and their definitions in relation to levies applied in Slovakia deserves a separate space for their examination and description. Therefore, for the purposes of this contribution, the author refers to this monetary fulfilment as a levy within the meaning of the legislation under consideration.

${ }^{3}$ In addition, a group of opposition parliamentarians of the National Council of the Slovak Republic filed a constitutional complaint to the Constitutional Court of the Slovak Republic to review the constitutionality of this act. Due to the repeal of the law, the Constitutional Court did not even decide on this complaint.
} 
On $2^{\text {nd }}$ April 2019, the European Commission ('the Commission') initiated proceedings against the Slovak Republic on the basis of the rules laid down in Article 108 (2) TFEU and at the same time within the meaning of Article 13 (1) of Council Regulation (EU) 2015/1589 the Commission adopted a decision suspending the possibility of granting any unlawful aid until the Commission took a decision on the compatibility of the aid with the internal market ${ }^{4}$. The decision of the Commission was not definitive, but was merely an interim measure with suspensory effect pending a detailed examination and a final decision on the fate of that law.

However, despite this, the Commission's decision ultimately led to the immediate submission of a proposal (mostly by the original proposers of the primary Act) for the adoption of an act repealing the Act on Special Levy of Retail Chains ${ }^{5}$. It is also worth noting that while 78 of the 135 present parliamentarians voted in favor of its adoption after returning the Act by the President, all 141 present parliamentarians voted in favor of its abolition ${ }^{6}$.

This atypical introduction is not purposeless. On the basis of this brief summary of the development and short existence of the Act on Special Levy of Retail Chains, it is reasonable to study if the parliamentarians by the immediate "capitulation" confirmed the lack of preparation, questionable feasibility, the discriminatory nature of this levy (tax) and the contradiction of this legislation with European Union law. Therefore, the objectives and hypothesis of the article in question can be established.

The main aim of the paper will be to evaluate the purpose and the objective of the Act on Special Levy of Retail Chains, its main shortcomings, contradiction with the theoretical bases of tax law and European law established by the scientific community, as well as other application shortcomings which ultimately led to the suspension of its application by a Commission decision and its subsequent cancellation by the National Council of the Slovak Republic. Then it will be possible to confirm or disprove the hypothesis whether the adoption of the Act on Special Levy of Retail Chains was justified, and this can be achieved by considering the quality of its preparation and implementation and the necessity of its abolition, and the adopted conclusion will also be an assessment criterion for assessing the level and quality of the current tax legislation in the Slovak Republic and its implementation in accordance with the requirements set out in the RIA 2020 - better regulation strategy.

\footnotetext{
${ }^{4}$ The Commission referred to a special levy on retail chains as a retail turnover tax, which, by its meaning, corresponds more closely to the wording and meaning of the Act on Special Levy on Retail Chains.

5 This was finally adopted by Act No. 88/2019 Coll. of 04 April 2019, which repealed Act no. 385/2018 Coll. on Special Levy of Retail Chains and on the amendment of Act no. 595/2003 Coll. on Income Tax, as amended, and amending Act no. 595/2003 Coll. on Income Tax as amended.

${ }^{6}$ The National Council of the Slovak Republic comprises altogether 150 parliamentarians.
} 
To achieve the stated goals and confirm or disprove the hypothesis, the author used several scientific methods, especially the methods of scientific analysis, synthesis and comparison by comparing the material requirements of this special levy with the strongly established and scientifically substantiated conclusions of tax law science.

\section{Special levy of retail chains - analysis and evaluation of selected aspects of the levy}

In order to assess this special levy in selected aspects as objectively as possible, it is necessary to highlight the aims and motives of the legislator, which were the basis for formation and adopting the act and its essentials.

According to the explanatory report of the Act on Special Levy of Retail Chains (which, by the way, is shorter than the act itself), the legislator justified the adoption of this act in the following way - the strategic economic interest of the Slovak Republic is to ensure its own food sovereignty, or to get as close to this food self-sufficiency as possible. The legislator therefore states that it is necessary to invest funds in agriculture and food. The distribution of value added across the food supply chain from primary production through food processing to sale is significantly uneven, with retail chains dominating the chain in terms of profit. In order to redistribute value added fairly throughout the chain, new mechanisms must be set up to support domestic agriculture and food and ensure their financing. In order to achieve these objectives, the present bill proposed to introduce an obligation to pay a special levy by entities that it defines as retail chains. In this context, the legislator considered it necessary to finance, in particular, the sales of agricultural products and food products, to finance analyzes, surveys, exhibitions and presentations related to the sales of agricultural products and food products.

The basic fiscal objective of the special levy was to tax turnover of retail chains selling food, which was subject to tax and taxable event at the same time. The entity of the levy was therefore the retail chain, which was defined directly by the act and which will be described and evaluated below.

The basis of levy was the net turnover ${ }^{7}$ of the retail chain defined by the act for the consecutive period of three consecutive calendar months of the relevant accounting period (essentially the entire calendar year) to which the levy rate of $2,5 \%$ was applied.

\footnotetext{
${ }^{7}$ For the purposes of the Act on Special Levy of Retail Chains, net turnover shall be understood as the proceeds from the sale of products, goods and services after deduction of discounts pursuant to the Article 2 (15) first sentence of Act No. 431/2002 Coll. on Accounting, as amended (hereinafter referred to as the "Act on Accounting").
} 


\subsection{Retail chain as an entity of levy - targeted individualization of levy?}

In the act, the legislature laid down the perception of the entity of levy on two levels. First of all, it was the perception of the entity of levy in a positive way, and therefore it was the retail chain that was obliged to pay a special levy. The act defined a mandatory retail chain as a grouping of commercial establishments that use the same or interchangeable trade name and which are operated by the same entrepreneur or interrelated property or personnel related entrepreneurs if:

1. is a food business operator ${ }^{8}$,

2. has shops in at least $15 \%$ of all districts ${ }^{9}$,

3. at least $25 \%$ of net turnover comes from the sale of food to final consumers,

4. shops have a unified design, common communication and common marketing activities

In a negative way (and hence without the obligation to pay the special levy) the retail chain has been defined for the purposes of this act in such a way that as the retail chain cannot be considered:

1. mass catering facilities ${ }^{10}$,

2. small and medium-sized enterprises ${ }^{11}$ (hereinafter referred to as the "SME"),

3. retail chain that sells food to the final consumer, with at least $80 \%$ of its net turnover coming from the sale of the food it produces,

4. retail chain linked to the producer of the food referred to in point 3 , where at least $80 \%$ of its turnover comes from the sale of food produced by the producer to which the retail chain is linked,

5. retail chain where at least $80 \%$ of his turnover originates from the sale of food of one class ${ }^{12}$.

\footnotetext{
${ }^{8}$ The Act referred to Article 3 (2) of the Regulation of the European Parliament and of the Council of 28 January 2002 laying down the general principles and requirements of food law, establishing the European Food Safety Authority and laying down procedures in matters of food safety.

${ }^{9}$ Considering the total number of 79 districts in the Slovak Republic, the retail chain had to have shops in 12 districts at least.

${ }^{10}$ Defined in Article 26 of Act on the protection, promotion and development of public health and on amendments to certain acts.

${ }^{11}$ The Act refers to the definitions of small and medium-sized enterprises laid down in the Commission Regulation of 17 June 2014 declaring certain categories of aid compatible with the internal market in application of Articles 107 and 108 of the Treaty.

${ }^{12}$ The determinant in this case was the sale of food of one class within the meaning of Commission Implementing Regulation of 12 October 2017 amending Annex I to Council Regulation (EEC) No 2658/87 on the tariff and statistical nomenclature and on the Common Customs Tariff.
} 
Nor should it be forgotten that if a retail chain were also subject to a levy, its individual shops would not be taxed if the legal conditions were met. This is related to the calculation of the levy basis. The act stipulated that the levy basis was the net turnover of the retail chain over the levy period. However, this calculation of the levy basis did not include the net turnover of the shops (together forming the retail chain), that were:

1. in districts included in the list of least developed districts ${ }^{13}$ and had a maximum of ten employees - these conditions had to be met cumulatively;

2. in a municipality where there are no more than three shops selling food to the final consumer - it should be noted that such a formulation was not exactly the happiest. It is not clear from that wording whether the existence of a maximum of three shops alone in a municipality is sufficient to exempt the net turnover of a shops from the levy basis, or whether the legislature meant a maximum of three shops under a single retail chain in that municipality

In view of the real state of operation of retail chains on the Slovak domestic market, it is necessary to state further facts in order to formulate the most objective conclusions. According to data for $2017^{14}$, 42 retail chains with an annual turnover of between 3 million EUR and 1.45 billion EUR carried out their business activities in the Slovak Republic, but only the 7 largest retail chains with annual turnover from 134 million EUR to 1.45 billion EUR would be entity of levy under the effective wording of the act. In addition, out of these 7 retail chains, even the two lowest-selling retail chains would be partially exempt from levy. The remaining 35 retail chains with an annual turnover of up to 100 million EUR would be totally exempted from this levy because they had shops in less than 12 districts at that time ${ }^{15}$.

Equally important is the exemption of retail chains on the basis of their definition as an SME. Taking into account the information submitted by the complainant, 26 of the 42 retail chains operating on the Slovak market in 2017 had a turnover of less than 50 million EUR and many of them would probably fell within the definition of small and mediumsized enterprises regarding the number of employees, respectively considering their overall annual balance sheet.

\footnotetext{
${ }^{13}$ That list shall be kept in accordance with the Article 3 (3) let. a) of Act on the support of the least developed districts and on amendments to certain acts by the Central Office of Labor, Social Affairs and Family. Currently, there are 20 districts out of a total of 79 districts, mainly from the eastern Slovak Republic.

${ }^{14}$ These data were part of a complaint submitted to the Commission, which had provisionally decided in the procedure for the assessment of unlawful State aid.

${ }^{15}$ According to the data submitted by the complainant, 25 of the 35 exempted retail chains with individual turnover ranging from 9 to 100 million EUR were members of a single trading alliance with a combined annual turnover of more than 1 billion EUR.
} 
According to the information provided by the complainant, retail chains owned by foreign persons, who at that time had a $45 \%$ share in the Slovak retail market, should have paid up to $99 \%$ of the total levy of retail chains. In view of such a comprehensive, detailed (and highly contradictory) and restrictive definition of the levy entity, it can be wondered whether the legislature intended to restrict the activities of selected retail chains on the Slovak retail market and thus grant unauthorized State aid those retail chains who are either not subject to the levy obligation, respectively to exempt them totally or partially from this obligation.

It is also worth noting that the legislative positive and negative definition of the retail chain as the entity of the levy obligation and the subsequent partial, respectively full exemption from the levy by not including net turnover in the levy basis cannot easily determine to whom the levy applied and in many cases this would be identifiable only after extensive accounting operations and evaluations. The individual conditions for the determination of the liable entity of the levy obligation are opaque, overlapping, not precise and not generally understandable. In application practice, they could create ambiguities with difficulties in determining the liable entity with obligation to pay this levy.

Significantly restrictive determination of the entity of the levy obligation and its apparent targeted individualization is in view of the established conditions and the real situation on the retail market prima facie discriminatory. The legislator had to dispose of this information in the process of lawmaking and the formulation of the rules creating the entity of the levy obligation shows that he knew about the facts about the condition of retail market. The question remains why in this way the legislature wanted to punish retail chains with a foreign ownership structure, which contribute to the development of the Slovak market and to the deepening of competition, which results in offering the best goods and services at the lowest possible price [Bujňáková 2016: 621-629].

However, it is an undeniable fact that large retail chains have a certain distorting effect on the market, even though it is not a dominant position under the competition rules. Although information about the efforts of large retail chains to exploit their market power and price dictates to put pressure on local producers is generally known, such behavior cannot be penalized by additional taxation of selected retail chains, as to control compliance with market mechanisms competent authorities are established in the Slovak Republic, such as Antimonopoly Office of the Slovak Republic. At the end of this part of the paper it is possible to express the idea whether, in the view of the presented facts, the act in question should not have been referred to as the Act on Levy of Special Retail Chains. 


\subsection{Other selected theoretical and legal shortcomings of the Act on Special Levy of Retail Chains}

The setting of a minimum net turnover from the sale of food to the end consumer, which the legislature set at $25 \%$, was also a significantly unjustified determining element of the retail chain. If the retail chain were to declare a $24,99 \%$ share of food sales in net sales, it would not be automatically the levy entity. It is easy to imagine that retail chains would automatically try to formally reduce the share of food sales by accounting operations, disguised acts and other activities in order to avoid paying the levy, respectively retail chains would reduce the real share of food sales in their sales offer. This suggests that poor quality and duly unjustified legislation can easily contribute to increasing tax evasion and tax fraud.

The second ambiguous and unreasonable element determining the entity of the levy obligation was that if the retail chain itself was a food producer and sold food to the final consumer and fulfilled all other obligatory requirements arising from Article 2 (1) let. a) of the Act on Special Levy of Retail Chains, if the retail chain reached the share of $25 \%$ of the sale of food, then it would be obliged to pay the levy, and if the retail chain reached the share of $80 \%$, it would not have this obligation. In this case, the behavior of the retail chains on the market could have been greatly affected in order to avoid the levy (causing possible disruption of shops, reduction of production capacity, redundancies, etc.).

The primary objective set by the legislator was a fairer redistribution of added value along the food supply chain. However, the legislator's stated endeavor is not reflected in the wording of the repealed Act on Special Levy of Retail Chains. The levy was based on the entire net turnover of the retail chain over the levy period. Anyhow, the reality is that the supply of retail chains is no longer formed only by food, but retail chains also sell goods in the drugstore, cosmetics, clothing, electronics, various types of technology etc., even some providing different services (financial services, mobile carrier services etc.). The legislature did not deal with this in the text of the act in any way, nor in the explanatory report to the act. Conversely, reflecting the purpose and declared objective of the act, the correct wording of the act would be if only the net turnover of the retail chain from the sale of foodstuffs were subject to the levy.

Doubts were also largely raised by the (un)declared method of redistributing the proceeds of the levy so as to achieve the objective and purpose laid down by act. The only rule for further use of this yield was only that the levy was an income of the budget chapter of the Ministry of Agriculture and Rural Development of the Slovak Republic and should be used mainly for the purpose of ensuring support for agriculture and food. Such a vague and demonstrative formulation of the use of levy, which was a material fulfillment of the 
objective of the act in question, cannot in any event be sufficient and satisfactory. Because of the importance and necessity of bringing this levy back into the food supply chain, it was necessary to lay down detailed, clear and comprehensible rules for its further use and fair distribution. In this situation, the yield of the levy was fully in the hands of the Ministry and could be used for other purposes than those declared by act. This can be perceived as one of the biggest shortcomings of the Act on Special Levy of Retail Chains.

The levy rate of a 2,5\% net turnover would, by its nature and substance, ultimately only contribute to the artificial increase in the price of the goods and services supplied by retail chains, and which would ultimately be borne by the final consumer (and what has been shown by recent practice, when retail chains automatically increased the prices of goods and services after the act was enacted). The sale of goods and services, the yield of which constitutes the net turnover of the retail chain, is primary already subject to value added tax, where the final consumer also bears the tax burden. For the same goods, respectively services, will increase in this way its taxation and it does not matter to what level, respectively in what form it will happen.

Another relatively serious shortcoming and unjustified rule was the establishment of net turnover as an indicator for determining the levy basis. Pursuant to Article 2 (15) first sentence in the Act on Accounting, net turnover is, in principle, understood as yield from the sale of products, goods and services minus discounts. It is clear from the above that the basis of the levy does not take into account in any way the costs of the retail chain spent on business and its further development. It can be stated that the fairer material base of the levy basis would be profit and not net turnover. Given the relatively low profitability of selling food, application the levy rate on the basis of the levy, which is made up of net turnover of the retail chain, could simply exceed the profit generated by the retail chain during the levy period. Such a situation would be clearly liquidating for the retail chain and unsustainable in the short term, but nor in the long term without the necessity to increase sales prices, respectively take other measures. At the same time, from the explanatory report or from other documents it is not apparent on the basis of which documents, analyzes and researches the legislature established the levy rate of 2,5\% and a net turnover as a determinant for determining the levy basis. The controversy of the legislature's conduct with the rules for implementing good law-making can be seen at first sight.

The Act on Special Levy of Retail Chains even contained a provision that could disrupted the organizational structure and system of financial administration authorities of the Slovak Republic. Pursuant to Article 11 (1) second sentence of this act, the Ministry of Agriculture and Rural Development of the Slovak Republic is the second-instance body in matters decided by the Financial Directorate of the Slovak Republic. On the contrary, according to then applicable Act on Authorities on State Administration Authorities in the 
Area of Taxes, Fees and Customs ${ }^{16}$, the Financial Directorate of the Slovak Republic was (and still is) the state administration body in the area of financial administration (taxes, fees and customs). For these reasons, it is incomprehensible why the Ministry tried to withdraw the power of decision-making as a second-instance body instead of the competent state administration body in this area. This is also related to the fact that the Act on Special Levy of Retail Chains did not define any case in which the Financial Directorate of the Slovak Republic should decide as a second-instance body. This provision therefore is considerable confusing and would likely to have created difficulties in its possible application.

\subsection{Act on Special Levy of Retail Chains in the context of principles of taxation of modern tax system}

The decisive criterion of the high quality of tax legislation is undoubtedly the need to formulate the wording of the act and the possibility of implementing the act in accordance with the principles of taxation defined by the theory of tax law [Sábo 2014: 376-384]. For preventive reasons it should be recalled that this quasi levy is in fact a tax, so it is essential for this levy ( $\operatorname{tax})$ to not collide with the principles of taxation. In accordance with the hypothesis set out in this paper, it is finally possible to assess whether the wording of the law and its possible implementation were contrary to the long-term known principles of taxation. Specifically, these are the principles of a modern and functional tax system - the principle of tax justice, the principle of elimination of double taxation, the principle of neutrality of taxation, the principle of simplicity and clarity of taxation and the principle of effectiveness (efficiency) of taxation [Babčák 2015: 50-55].

The essence of the principle of tax justice is defined in particular by ethical and moral aspects and as such consists in the contribution of each taxable person to the payment of common expenses in an adequate and proportionate manner. In the theory of tax law is recognized by its perception in two levels, namely horizontal and vertical. In the case of horizontal justice, the same subject-matter of taxation should be taxed in the same way and with the same tax rate. Entities that have the same paying capacity should pay the same taxes, so taxable persons with the same income should pay the same amount of tax. On the other hand, vertical justice reflects the fact that a taxable person who has higher incomes, larger assets or participates in the consumption of taxable items in a greater extent should

\footnotetext{
${ }^{16}$ Act on Financial Administration and on Amendments to Certain Acts effective from 01 July 2019, repealed the abovementioned and other acts, replaced them in full and unified them and for the purposes of this article it can be stated that their content and meaning have not been substantially altered.
} 
pay a correspondingly higher tax while maintaining the proportionality of taxation ${ }^{17}$ [Musgrave 1994: 206]. There is no doubt that the special levy of retail chains did not meet these elementary requirements, which are determined by the importance of the principle of tax justice. The act purposely and without adequate justification established a group of persons whose were subject to the levy obligation and at the same time, without justification, defined the persons not subject to such an obligation, respectively established the form of partial or total exemption from the levy without due justification supported by the facts and evidence. This act resulted in different treatment with objectively comparable retail chains, regardless of the fact that they achieved the same income and would normally be taxed in the same way. The retail chain due to its activities in 12 districts would be subject to the levy in part or in full, and a retail chain would not be subject to this levy at all if it met the condition of activities (have shops) in 11 districts - this is one of many example of the manifest injustice of this act. The application of the principle of tax justice was thus severely restricted by the act and its possible implementation would probably be considerably unfair, in both its levels.

The principle of elimination of double taxation is based on the fact that the same income or property of the same person must be taxed only once (by one tax). On the other hand, the entire net turnover of the retail chain for the levy period was subject to the levy (if it was obliged to pay this levy). It means, that all revenues from total sales of all goods and services of the retail chain were again subject to direct tax (levy). By introducing this levy, the retail chains increased their prices and thus the final consumer was ultimately the bearer of the tax burden. The levy in question was therefore actually capable of producing the effect of double taxation of goods and services, albeit indirectly.

The principle of neutrality of taxation can be expressed as a rule according to which taxation must be neutral in the sense that it does not distort economic processes and that it minimizes the economic behavior and decision-making of taxable persons. This can be achieved by minimizing state interference in the economy [Cakoci 2018: 106-120]. Generally, tax (levy) should not affect the state and development of the national economy and should not affect the behavior of economic entities [Babčák 2014: 9-26]. On the basis of the theoretical and possible application shortcomings of the special levy of retail chains, it can be concluded without any doubt that perhaps there is no principle of taxation, the application of which would be more limited. The legal definition of the retail chain and the associated levy obligation prompted retail chains to adapt their economic behavior and results directly to avoid levy. On the other hand, in this way the state tried to raise funds for activities that could be financed from other sources (not only from the state budget, but also, for example, from the European Union's funding system). Nor can we neglect

\footnotetext{
${ }^{17}$ In tax law theory, this is also referred to as the requirement of the same victim formulated by Richard A. Musgrave.
} 
violating this principle by increasing state intervention in the competition and the market economy.

By consistently observing the principle of simplicity and clarity of taxation, it would be possible to achieve unambiguous, transparent and easy to understand tax acts, their uniform and unambiguous interpretation, uncomplicated way of calculating tax (levy) obligations, low tax administration costs, etc. This principle, by its very nature, incorporates the requirement of continuous effort to make tax legislation as simple and straightforward as possible. However, a number of proven shortcomings of the repealed Act on Special Levy of Retail Chains have violated consistently and successfully the fulfillment of this principle of taxation. Not only was this law not unambiguous, given its small scope, it was also quite complex and brought more questions than answers. In general, and in the law-making process in particular, the rule - the less text the better cannot be applied. It will be difficult to find a better example of violating this principle in the Slovak tax legislation. In this levy, it was possible to identify, for example, ambiguous terminology, confusing definition of legal definitions, non-systemic and, in all probability, incorrect interference in the competency structure of state administration bodies and contradiction of the planned objective of the law with expected real status and utilization of levy.

According to the knowledge of modern science of Slovak tax law [Babčák 2019: 116-138], the principle of effectiveness (efficiency) of taxation can be characterized as an effort of the state to use taxes (levies) not only as a means of obtaining financial resources into state or local budget, but also as an active instrument of economic and social policy of the state. Its other meaning is that the yield from the tax (levy) should be reasonably high in order to fulfill its fiscal function, so administrative and other tax-related costs on the side of the taxable person and the tax administrator must be proportionate to the revenue from the tax collection. Equally effective taxation is also taxation that eliminates the possibility of tax evasion and tax fraud. It cannot be concluded that the repealed special levy on retail chains fulfills these requirements within the validity and application of this principle. Although the purpose of the act was formulated with the aim of fair redistribution of revenue to alleviate the uneven distribution of value added in the food supply chain from primary production through food processing to sale, the wording of the act does not reflect these initiatives and its implementation would probably not eliminate its injustice. At the same time, administrative costs cannot be considered insignificant, as the wording of the act implies an obligation to ascertain the amount of net turnover and its composition (sale of foodstuffs) in order to determine whether or not the retail chain is the taxable entity (the levy entity). It is possible to imagine the absurdity and meaninglessness of carrying out a number of complex accounting operations, finding that the retail chain is not obliged to pay a levy due to the low (or high) share of food sales in total net turnover. Contrary, the 
above mentioned facts directly make the tax administration more costly and difficult to control these retail chains.

The repealed special levy on retail chains was a step backwards from the point of view of modern tax law science. On the basis of the above analysis and comparison results, it can be concluded from the theoretical and legal point of view that its repealing was justified, regardless of the reasons for its repeal. This levy (tax) significantly violated by its nature the applied and valid principles of taxation. Its application could lead to significant distortions of the retail market, to irreversible consequences for levied entities and to a significant distortion of economic competition.

\section{Helping hand provided by the Commission - repealed levy as an unlawful State aid?}

As mentioned in the introduction to this contribution, the Commission adopted the decision pursuant to Article 13 (1) of Council Regulation (EU) 2015/1589 to suspend the possibility of the Slovak Republic to grant any unlawful aid until the Commission has taken a decision on the compatibility of the aid with the internal market. The decision after all led to the repeal of the Act on Special Levy of Retail Chains on the own initiative of submitters of the original act. It was based on the fact that the Slovak Republic should have infringed European Union law by implementing this law and thus grant unlawful State aid to selected entities in the single internal market. In order to reach further conclusions on the existence of an infringement of European Union law, it was necessary to establish the existence of unlawful State aid. The achieved results can be applied to complete the context in proving, respectively refuting the hypothesis set out in the introduction.

Pursuant to the provisions of Article 107 (1) TFEU shall apply as follows: "Save as otherwise provided in the Treaties, any aid granted by a Member State or through State resources in any form whatsoever which distorts or threatens to distort competition by favouring certain undertakings or the production of certain goods shall, in so far as it affects trade between Member States, be incompatible with the internal market". The existence of unlawful aid granted by Member States is therefore conditional on the cumulative fulfillment of the following conditions - the measure must be imputable to a Member State and financed by State resources, the measure must confer an advantage, the advantage must be selective and the measure must distort competition or threaten to distort competition and affect trade between Member States of the European Union.

Due to the adoption of the Act on Special Levy of Retail Chains by the National Council of the Slovak republic, the imputability of the measure to the Slovak Republic is clearly demonstrated. 
It may seem that by the introduction of a new tax (levy) cannot be fulfilled the condition of financing from State resources, since that condition evokes the necessary of active action of the Member States or active making payments as unauthorized State budget aid. This deficiency has been remedied by the decision-making of the Court of Justice of the European Union (hereinafter: $\mathrm{CJEU}$ ), which made clear that in case of waiving the income by state that would normally be collected from the enterprise, the condition of financing from state funds is also met [CJEU: C-83/98 $]^{18}$. Unjustified exemptions in the Act on Special Levy on Retail Chains were likely to fulfill this obligatory condition, as the Slovak Republic thereby waived the resources that it would otherwise be entitled to collect from enterprises which were fully or partially exempt from payment of the levy.

Another necessary condition for the occurrence of unlawful State aid is the identification and existence of an advantage to the enterprise. The CJEU ruled that a measure by which the public authorities grant certain undertakings favourable tax treatment which, although not involving the transfer of State resources, places those to whom it applies in a more favourable financial position than other taxpayers constitutes State aid within the meaning of Article 107(1) TFEU [CJEU: C-417/10]. Furthermore, in the judgment of CJEU held that, as regards fiscal measures, which grants to certain undertakings a tax reduction or a deferral of liability to tax that would otherwise be payable may constitute State aid [CJEU: C-66/02]. However, the existence of an exemption from payment of the levy did not in itself confer an advantage on a particular undertaking over other undertakings. The problem became only when it was possible to investigate the selective elements not only of exempting the company from paying that levy, but also the selectivity of taxation of specific retail chains. Given the prevailing individualization and illicit concretization shown above, it could be stated that the implementation of the law would indeed bring an economic advantage to those retail chains that would not be unjustifiably taxable entity.

In order to assess whether another condition has been met, it is necessary to take into account whether the Act on Special Levy on Retail Chains provided selective benefits and it requires a determination, in the first place, of whether this national measure is such as to favour "certain undertakings or the production of certain goods" over other undertakings which, in the light of the objective pursued by that regime, are in a comparable factual and legal situation and which accordingly suffer different treatment that can essentially be classified as discriminatory [CJEU: C-374/17]. In the foregoing, the author pointed out many of the discriminatory elements of the act in question which would arise from its implementation, and which relate in particular to the incoherent, complicated and overlapping exemption from payment of the levy on the basis of various unjustified

\footnotetext{
${ }^{18}$ This applies mutatis mutandis to a measure which allows certain enterprises to reduce or defer payment of the normal due tax (CJEU: joined cases C-78/08 until C-80/08).
} 
conditions. Given that only 7 retail chains out of a total of 42 would be likely to be liable to pay the levy, this act can be described as being highly discriminatory. Comparable retailers in a comparable factual and legal situation would be subject to considerably different treatment by the implementation of this act.

The last condition of unlawful State aid granted under a measure (law) of a Member State is the need to distort competition or threaten to distort it and affect trade within the European Union. At this point, it is necessary to point out that the Slovak Republic is the Member State of the European Union and is part of the single internal market in which open competition is taking place. It is clear at first sight that the retail chains exempted from the levy had an improved position and that exemption could have improved their competitive position vis-à-vis the retail chains subject to the levy. Therefore, this exemption had to be considered as unlawful aid which distorts or threatens to distort competition, since it strengthens the economic position of retail chains not paying this levy on the retail market. In accordance with the CJEU's settled case-law, for the purpose of categorising a national measure as State aid, it is necessary, not to establish that the aid has a real effect on trade between Member States and that competition is actually being distorted, but only to examine whether that aid is liable to affect such trade and distort competition [CJEU: C-518/13; CJEU: joined cases C-197/11 and C-203/11; CJEU: T288/97].

Before the final evaluation, it should be noted that not each State aid is unlawful, but under certain conditions such State aid is compatible with the internal market. These exceptions are directly laid down, for example, in Article 107 (2) and (3) and in Article 106 (2) TFEU. At the same time, it is the responsibility of each Member State to demonstrate that such State aid is compatible with the internal market in accordance with Article 107 (2) or (4) TFEU [CJEU: T-68/03].

Following such an analysis, it is possible to unequivocally identify with the procedure of the Commission, which by decision temporarily suspended the effect of the already repealed Act on Special Levy of Retail Chains. The Slovak authorities have not even put forward any reasonable arguments as to why the act and its implementation should be compatible with the internal market of the European Union. On the basis of the above, it can therefore be concluded that the Act on Special Levy of Retail Chains directly violated European Union law and this State aid was not compatible with the internal market as required the European Union law. Despite the apparent lack of preparation of the wording of the act, the deficiency of an assessment of all possible impacts and its apparent conflict directly with the founding treaties of the European Union, the Slovak legislature directly declared in the explanatory report and other documents that the act complies with European Union law. Such a procedure does not contribute to increasing the level and quality of Slovak tax legislation. 


\section{The process of adopting the repealed Act on Special Levy of Retail Chains in the context of RIA 2020 - Better Regulation Strategies}

On the initiative of the Ministry of Economy of the Slovak Republic as the national coordinator of the better regulation agenda was adopted the RIA 2020 - better regulation strategy by the Government Resolution no. 32/2018. The basic objective of this strategy and the long-term continuous priority of the Government of the Slovak Republic is to facilitate business by eliminating unjustified regulatory barriers and bureaucracy, which causes additional financial costs or time burden. This effort should be part of the wider agenda of better regulation, which will not only be aimed at entrepreneurs but also by optimizing the regulatory environment to all citizens of the Slovak Republic.

The strategy itself contains a set of principles and tools, the implementation of which should ultimately lead to the optimization of the regulatory environment and increase the transparency of all law-making and non-legislative documents, secondary to the improvement of the business environment.

RIA 2020 has set objectives such as raising public awareness of better regulation, improving the quality of the ex ante impact assessment process, introducing systematic ex post evaluation of regulations, implementing innovative regulatory approaches and creating the conditions for involving other actors in better regulation activities.

Under these rules, the government has set itself the objective of adopting regulations to work closely with business and the public and presented the so-called regulatory cycle. Prior to the adoption of regulation, the process should have started with a preparatory phase during which the government should have actively consulted on the draft law with public, submitting alternatives, commenting, ex ante impact assessments, etc. Only then should the act itself be adopted, respectively regulation as such. After that, there should be an implementation phase in which the government should carry out monitoring in the area of regulation, analyze the effectiveness and efficiency ex post and thus eliminate further shortcomings of regulation, and the whole process should start again in order to remedy the identified shortcomings.

The above mentioned scheme, undoubtedly fully applicable also to the repealed special levy under consideration, was not applied in any respect when the act was adopted. Not only it was not preceded by public debate and comments by the concerned parties, but also the submitters of this act themselves did not provide sufficient evidence to properly justify the proposed wording of the act. Despite several statements by the government regarding the intention to adopt such a special levy on retail chains, the law was finally submitted to the National Council of the Slovak Republic as a parliamentary proposal. In this way, the possibility of a wide-ranging society discussion was circumvented. 
Indeed, we can express concern about the way in which the government and the parliamentarians of government parties work. In such an obstructive way on such an important and challenging issue as taxation, it was almost potentially affected the retail market by disproportionate interference, which was able to unnaturally distort the position of individual retail chains and unduly favor some retail chains over others.

\section{Conclusion}

By examining in detail the selected aspects of the repealed Act on Special Levy of Retail Chains, it was possible to conclude and refute the hypothesis that adoption of the act was justified. This conclusion was adopted on the basis of an in-depth examination of its (poor) quality, ambiguity and confusion, theoretical and application deficiencies, its direct and insurmountable contradiction with the very principles of taxation and, ultimately, its very likely collision with the European Union law.

The knowledge gained by scientific activities in the evaluation of this act and the merits of its adoption have also been useful in assessing the level and quality of Slovak tax legislation. It is regrettable that the way in which the law was adopted showed a number of signs of purposeful behavior by lawmakers deliberately circumventing the RIA 2020 better regulation rules adopted at government level to gradually improve the quality of Slovak law, drafting, implementing and realizing it. It can be assumed that this act would have little chance of being passed as amended if maintaining the procedure foreseen by the better regulation strategy of the RIA 2020.

The absence of public and concerned parties participation in the preparation of this tax legislation is a critical failure of the Slovak legislator. The deficiency of justification, the lack of proper research and the assessment of the effects of the new legislation on the business environment and the retail market have dramatically reduced the legal feasibility of this act and these deficiencies have been fully reflected in reality. With regard to the legislator's procedue leading to the abolition of the Act on Special Levy of Retail Chains and due to the selective taxation of selected retail chains, there can be reason to doubt the reasons to adopt this act presented by the legislator.

Fortunately, the repealed Act on Special Levy of Retail Chains did not have a long lifetime, but perhaps the fate of this act will be an important memento for the Slovak legislator in the distant future. Establishing a new tax (levy, fee) has to be duly substantiated, terminologically perfect, prepared after a wide-ranging society discussion and taking into account professional and scientific knowledge reflecting the real legal and economic situation in the taxed area. 


\section{References:}

Babčák, V.: Daňové právo ako forma a nástroj pôsobenia štátu na ekonomické vztahy [Tax Law as a Form and Instrument of State Influence on Economic Relations], in: Právo, obchod, ekonomika IV.: zborník vedeckých prác [Law, business, economics IV.: conference proceedings of scientific works], Košice: Univerzita Pavla Jozefa Šafárika v Košiciach, 2014.

Babčák, V.: Daňové právo na Slovensku [Tax Law in Slovakia], Bratislava: EPOS, 2015.

Babčák, V.: Daňové právo na Slovensku a v EÚ [Tax Law in Slovakia and in EU], Bratislava: EPOS, 2019.

Boháč, R.: Daňové př́ijmy veřejných rozpočtů v České republice [Tax Revenue of Public Budgets in the Czech Republic], Praha: Wolters Kluwer ČR, 2013.

Bujňáková, M. et al: The Impact of legislation on Foreign direct Investment in Slovak Republic, in: SGEM 2016: Political sciences, Law, Finance, Economics and Tourism, vol. III: 3rd International multidisciplinary scientific conference on social sciences and arts: 24. - 30. august 2016, Albena, Bulgaria, Sofia: STEF92 Technology, 2016.

Cakoci, K. et al: Daňová politika a jej vplyv na kreovanie podnikatel'ského prostredia (teoretické východiská) [Tax Policy and its Impact on Creating Business Environment (Theoretical Background)], in: Dny práva 2017: část III. Stabilita a stabilizace podnikatelského prostředí: 9.-10.11.2017, Brno [Days of Law 2017: Part III. Stability and stabilization of business environment: 9.-10.11.2017, Brno], Brno: Masarykova univerzita, 2018. Also available at: www.law.muni.cz/dokumenty/44813.

Kiska, A.: Decision of the President of the Slovak Republic to return the Act of 06 December 2018 on Special Levy of Retail Chains and on amendment of Act No. 595/2003 Coll. on Income Tax as amended, 2018.

Musgrave, R. A. et al: Veřejné finance v teorii a praxi [Public Finance in Theory and Practice], Praha: Management Press, 1994.

Sábo, J.: Princípy daňového práva a daňová politika štátu - alebo existuje hranica, ktorá sa nesmie prekročit? [Principles of tax law and state tax policy - or is there a limit that must not be exceeded?], in: Poňatie a charakter práva: zborník príspevkov $\mathrm{z}$ medzinárodnej vedeckej konferencie: 27. február 2014 [The concept and nature of law: Proceedings of the International Scientific Conference: 27 February 2014], Bratislava, Bratislava: SAP - Slovak Academic Press, 2014.

\section{Legal Acts and Official Documents:}

Act no. 333/2011 Coll. on Authorities on State Administration Authorities in the Area of Taxes, Fees and Customs as amended.

Act no. 336/2015 Coll. on the support of the least developed districts and on amendments to certain acts as amended.

Act no. 35/2019 Coll. on Financial Administration and on Amendments to Certain Acts.

Act no. 355/2007 Coll. on the protection, promotion and development of public health and on amendments to certain acts, as amended by Act No. 355/2016 Coll. 
Act no. 385/2018 Coll. on Special Levy of Retail Chains and on the amendment of Act no. 595/2003 Coll. on Income Tax as amended.

Act No. 431/2002 Coll. on Accounting, as amended.

Act No. 88/2019 Coll. of 04 April 2019, which repealed Act no. 385/2018 Coll. on Special Levy of Retail Chains and on the amendment of Act no. 595/2003 Coll. on Income Tax, as amended, and amending Act no. 595/2003 Coll. on Income Tax as amended.

Commission Implementing Regulation (EU) 2017/1925 of 12 October 2017 amending Annex I to Council Regulation (EEC) No 2658/87 on the tariff and statistical nomenclature and on the Common Customs Tariff.

Commission Regulation (EU) No 651/2014 of 17 June 2014 declaring certain categories of aid compatible with the internal market in application of Articles 107 and 108 of the Treaty, as amended.

Regulation (EC) No 178/2002 of the European Parliament and of the Council of 28 January 2002 laying down the general principles and requirements of food law, establishing the European Food Safety Authority and laying down procedures in matters of food safety, as amended.

State Aid SA.52194 (2018/FC) - Slovak Retail Turnover Tax - Invitation to submit comments pursuant to Article 108 (2) of the Treaty on the Functioning of the European Union (2019/C 194/03).

\section{Court Decisions:}

Court of Justice of the European Union: C-83/98.

Court of Justice of the European Union: C-66/02.

Court of Justice of the European Union: joined cases C-78/08 until C-80/08.

Court of Justice of the European Union: C-417/10.

Court of Justice of the European Union: joined cases C-197/11 and C-203/11.

Court of Justice of the European Union: C-518/13.

Court of Justice of the European Union: C-374/17.

Court of Justice of the European Union: T-288/97.

Court of Justice of the European Union: T-68/03. 